\title{
KEBIJAKAN PEMERINTAH DALAM PEMBANGUNAN YANG BERBASIS KEARIFAN LOKAL MENUJU MASYARAKAT SEJAHTERA DI KABUPATEN TELUK BINTUNI PAPUA BARAT
}

\author{
Karsiman \\ Program Studi Ilmu Administrasi Negara \\ Universitas Muhammadiyah Sorong \\ Karsiman@um-sorong.ac.id
}

\begin{abstract}
Abstrak
Penelitian ini bertujuan untuk mengetahui kebijakan pembangunan berbasis kearifan lokal di Kabupaten Teluk Bintuni. Teknik pengumpulan data yang digunakan yaitu; observasi, wawancara, dan dokumentasi. Metode analisis yang digunakan adalah analisis kualitatif. Hasil penelitian menunjukkan bahwa Kebijakan pembangunan di Kabupaten Teluk Bintuni senantiasa memperhatikan keinginan dari 7 Suku Besar yang ada di Kabupaten Teluk Bintuni. Adapun setiap investor yang datang menanamkan modalnya di Kabupaten Teluk Bintuni senantiasa memperhatikan pembangunan sumber daya manusia 7 suku besar yang ada di Kabupaten Teluk Bintuni.
\end{abstract}

Kata Kunci: Kebijakan, Pembangunan, dan Kearifan Lokal

\section{PENDAHULUAN}

Pembangunan merupakan aktivitas yang dilakukan oleh pemerintah, masyarakat, dan pihak swasta berlangsung secara terus-menerus dan berkesinambungan dengan tujuan untuk meningkatkan kesejahteraan rakyat, baik pada aspek materiil maupun spiritual (Afandi \& Warjio dalam Ramdhani \& Ramdhani, 2016). Pembangunan perlu dikendalikan melalui suatu kebijakan yang memuat pedoman pelaksanaan tindakan dan bahkan memuat larangan-larangan tertentu untuk menjamin proses pembangunan dapat terarah sesuai dengan tujuan yang telah ditetapkan. Pelaksanaan kebijakan tidak hanya menyangkut perilaku lembaga administratif yang bertanggung jawab untuk melaksanakan program, melainkan menyangkut pula pada partisipasi masyarakat, kekuatan politik, ekonomi dan sosial dengan berbagai pihak. Pelaksanaan kebijakan yang dilaksanakan secara tepat sasaran dan berdaya guna akan mampu memecahkan suatu permasalahan secara baik, semakin kompleks permasalahan kebijakan dan semakin mendalam analisis yang digunakan, semakin diperlukan teori dan modal yang mampu menjelaskan ketepatan pelaksanaan kebijalan tersebut (Rohman, dalam Ramdhani \& Ramdhani, 2016)). Analisa kebijakan perlu dilakukan, tertutama berkenaan dengan dampak yang dihasilkannya. Kajian pelaksanaan kebijakan bertujuan agar suatu kebijakan tidak bertentangan dan merugikan kepentingan masyarakat.

Bila kita mencermati pembangunan daerah bahwa sejak kejatuhan rezim Orde Baru pada tahun 1998, awal terjadinya paradigma pembangunan masyarakat di negeri tercinta ini menjadi wacana yang selalu aktual untuk dibicarakan sampai sekarang. Hal ini setidaknya tercermin dari tema:"Reformasi Model GBHN (Garis Besar Haluan Negara) Mewujudkan sistem 
Perencanaan Pembangunan Nasional dan Daerah yang berorientasi pada kesejahteraan rakyat. Menurut (Husnul Imtihan, Wahyunadi, 2017) Negara didirikan dengan satu tujuan utama, yakni untuk memberikan kesejahteraan bagi masyarakat. Termasuk dalam hal ini antara lain adalah kemakmuran, kesehatan, pendidikan, dan rasa aman bagi rakyatnya serta meningkatkan harkat dan martabat rakyat sebagai manusia. Oleh karena itu negara membentuk suatu organisasi yang bernama pemerintah sebagai pemegang mandat kekuasaan negara untuk merencanakan, menetapkan tujuan, dan sasaran. Untuk tercapainya keberhasilan pembangunan masyarakat di Daerah maka segala program perencanaan, pelaksanaan serta evaluasi pembangunan harus melibatkan masyarakat, karena merekalah yang mengetahui permasalahan dan kebutuhan dalam rangka membangun wilayahnya.

$$
\text { Menurut (Edyanto, }
$$

Kepemimpinan dibutuhkan manusia karena adanya suatu keterbatasan dan kelebihankelebihan tertentu pada manusia. Di satu pihak, manusia terbatas ke-mampuannya untuk memimpin, di pihak lain ada orang yang mempunyai kelebihan kemampuan untuk memimpin. Di sinilah tim-bulnya kebutuhan akan pemimpin dan kepemimpinan. Lebih lanjut, Menurut (Soares, Nurpratiwi, \& Makmur, 2015) Peranan pemerintah daerah dalam perencanaan pembangunan daerah mempunyai kewenangan yang sangat strategis dan kedudukan yang strategis hal ini berkaitan dengan fungsinya selaku "pelayanan publik" guna meningkatkan kesejahteraan, kemakmuran, keamanan, keadilan dan ketenteraman bagi masyarakat. Ndraha (dalam Soares et al., 2015) menyatakan bahwa peranan pemerintah dalam pembangunan masyarakat amat luas, berawal dari hal yang bersifat pelayanan operasional sampai pada hal yang bersifat ideologi dan spiritual dengan ini peran pemerintah akan mempunyai wewenang dan kemampuan seseorang tersendiri untuk melaksanakan tugas pokok dan fungsinya seorang pemimping, karena tuntutan dari tugas pokok dan fungsinya sendiri bisa menyelesaikan persoalan-persoalan dilingkungan masyarakat maupun pemerintah. Menurut (Safri Miradj, 2014) Inti dari tujuan pembangunan adalah mewujudkan suatu masyarakat yang makmur dan sejahtera baik secara individual maupun secara sosial. Hal ini dimaksudkan agar makin tumbuh kesadaran masyarakat, pentingnya pendidikan agar dapat mendorong masyarakat untuk terus berpartisipasi aktif di dalam merespon pembangunan yang berkelanjutan. Hal Ini disebabkan pada faktor yang lebih dominan yang mempengaruhi persoalan dari segi kemanusiaan dan pembangunan, seperti keterbelakangan, kebodohan, ketelantaran, kematian dini, buta huruf, anak putus sekolah, anak jalanan, pekerja anak, perdagangan manusia (human trafficking) dan penganguran, ini yang membuat sebagian masyarakat kita tidak dapat menikmati kehidupannya dengan sejahtera.

Kearifan lokal merupakan suatu istilah yang mencuat ke permukaan dengan mengadopsi prinsip, nasihat, tatanan, norma, dan perilaku leluhur kita masa lampau yang masih sangat urgen untuk diaplikasikan dalam menata berbagai fenomena yang muncul. Kearifan lokal tidak terlepas dari kearifan budaya setempat. Istilah kearifan, biasanya dikenakan pada masalah lingkungan, yaitu hubungan timbal balik antara manusia dan lingkungannya. Manusia berperang ganda, yaitu sebagai subjek yang 
mempengaruhi lingkungan dan sebagai objek yang dipengaruhi lingkungannya. Kearifan berarti kebijakan (wisdom) mengola alam, agar lingkungan tetap lestari. Keberadaan kearifan-kearifan lokal yang memiliki peran signifikan. Oleh karena itu, keberadaan kearifan lokal sudah sepantasnya mendapat perhatian untuk dikembangkan menjaga kerukunan hidup umat beragama. Kearifan di dalam masyarakat lokal ada yang berupa tradisi dan praktek terbaik (best practice) yang terjelma dalam tingkah laku, dan ada pula yang dalam bentuk ungkapan-ungkapan dan pesanpesan. Tradisi lisan dalam bahasa lokal merupakan sarana utama penerusan pesanpesan tersebut dari generasi ke generasi. Ketika tradisi lisan mulai terdesak oleh ruang ekspresi yang dipenuhi budaya popular, masih ada harapan ke tradisi rulisan yang masih tersisa (Darwis Muhdina, 2015). Lebih lanjut, Menurut (Jupir, 2013) budaya dalam beragam manifestasinya menjadi daya tarik dan pendorong bagi wisatawan yang berkunjung ke suatu tempat dan menjadi objek konsumtif yang menarik di bidang pariwisata karena di dalamnya mengadung pengalaman (experience). Berangkat dari uraian diatas maka penulis tertarik untuk meneliti tentang 'Kebijakan pembangunan berbasis kearifan lokal di Kabupaten Teluk Bintuni’’

\section{METODE PENELITIAN}

\section{Lokasi Penelitian}

Penelitian ini dilaksanakan di Kabupaten Teluk Bintuni Provinsi Papua Barat.

\section{Jenis Penelitian}

Jenis penelitian ini adalah penelitian secara kualitatif artinya penulis mengumpulkan data tidak menggunakan statistik, dimana penulis akan meneliti dengan memberikan pertanyaan-pertanyaan kepada responden untuk mendapatakan data-data. Pendekatan deskriptif kualitatif bertujuan untuk memberikan gambaran secara jelas mengenai kebijakan pembangunan di Kabupaten Teluk Bintuni. Dalam pendekatan kualitatif ini, peneliti terjun langsung di Kabupaten Teluk Bintuni untuk mendapatkan informasi secara mendalam mengenai Kebijakan Pembangunan Di Kabupaten Teluk Bintuni berbasis kearifan Lokal.

\section{Jenis dan Sumber data}

Jenis dan sumber data berpedoman pada data primer maupun data sekunder dimana penulis akan memperoleh data dengan cara wawancara dan memperoleh data yang sudah disediakan dalam bentuk dokumen yang berkaitan dengan objek penelitian.

\section{Teknik Pengumpulan Data}

Teknik pengumpulan data yang penulis gunakan dalam penelitian ini adalah pengamatan langsung di lapangan (observasi), wawancara, Studi Pustaka, Studi Dokumentasi.

\section{Teknik Analisis Data}

Dalam menganalisa suatu data dan pemecahan masalah untuk mempermudah penulis dalam menafsirkan data-data yang telah dikumpulkan dan diolah, maka penulis menggunakan analisa kualitatif.

\section{HASIL DAN PEMBAHASAN}

Kebijakan pembangunan berbasis kearifan lokal adalah kebijakan di bidang pembangunan yang mengedepankan segala bentuk keunikan yang dimiliki oleh suatu komunitas atau daerah tertentu yang mengandung nilai-nilai kebudayaan baik yang bersifat material maupun non-material, adapun kebijakan pembangunan berbasis 
kearifan lokal di Kabupaten Teluk Bintuni, diantaranya:

A. Partisipasi Masyarakat (7 Suku Besar Di Kabupaten Teluk Bintuni).

Partisipasi masyarakat dalam pembangunan di Kabupaten Teluk Bintuni sangat menentukan kebijakan pembangunan di Kabupaten Teluk Bintuni. Secara umum pemerintah daerah sudah meletakan dasar pembangunan daerah dan itu dimuat dalam visi dan misi bupati dan wakil bupati. Pemerintah dalam melaksanakan pembangunan yang selama ini berlangsung ada prioritas pembangunan yang di lakukan yakni masing-masing di bidang infrastruktur, pendidikan, dan kesehatan dengan memperhatikan kearifan lokal di Kabupaten Teluk Bintuni. Partisipasi Masyarakat merupakan modal dasar dalam pembangunan dalam suatu daerah.

Sama halnya dalam setiap komunitas masayarakat senantiasa terdapat proses politik dan distulah dilahirkan pemimpin, dalam kepemimpinan itu ada seorang pemimpin, menyusun organisasi, memperoleh dan menggunakan kekuasaan. Orang Teluk Bintuni mengenal sistem kepemimpinan sejak nenek moyang mereka. Di Kabupaten Bintuni adalah 7 kelompok sub suku besar yang mendiami teluk Bintuni antara lain sub suku Wamesa, Sebyar, Kuri, Irarutu, Moskona, Sumuri dan Sough. 7 Suku besar inilah yang memegang peranan penting dalam pemerintahan Kabupaten Teluk Bintuni. Dalam hal ini, setiap pengambilan kebijakan haruslah senantiasa memperhatikan aspirasi dari masyarakat 7 suku besar di Kabupaten Teluk Bintuni. Dalam Visi Misi Pemerintah Daerah, Investor yang masuk hendaknya memperhatikan 7 suku besar masyarakat Bintuni.
Berdasarkan hasil wawancara dengan Sekretaris DPRD Kabupaten Teluk Bintuni berinisial ED, mengemukakan bahwa :

"..... Kebijakan pembangunan di Kabupaten Teluk wajib memperhatikan kemauan dan aspirasi dari 7 Suku besar itu, sekiranya kebijakan itu tidak sejalan dengan keinginan dari 7 suku besar itu maka kebijakan itu harus dihentikan". (Hasil wawancara 2019).

Hasil wawancara dengan informan dari pihak Dinas Pendidikan Kabupaten Teluk Bintuni, mengemukakan bahwa:

',.......Pokoknya kuncinya ada pada kemauan 7 suku besar ini, kalau sekiranya mereka 7 suku besar itu tidak mau maka kebijakan tidak akan berjalan, maka hendaknya 7 suku besar itu harus diperhatikan',. (Hasil wawancara 2019).

Berdasarkan hasil wawancara diatas diperoleh informasi bahwa kebijakan pembangunan di Kabupaten Teluk Bintuni senantiasa memperhatikan keinginan dari 7 Suku Besar yang ada di Kabupaten Teluk Bintuni. Hal ini mengangdung arti bahwa Pembangunan yang dilakukan dilaksanakan di Kabupaten Teluk Bintuni senantiasa memperhatikan Kearifan lokal atau Local Wisdom yang merupakan gagasan-gagasan atau nilai-nilai, pandangan pandangan setempat atau lokal yang bersifat bijaksana, penuh kearifan, bernilai baik yang tertanam dan diikuti oleh anggota masyarakatnya. Untuk mengetahui kearifan lokal di suatu wilayah maka kita harus bisa memahami nilai-nilai budaya yang baik yang ada di dalam wilayah tersebut. Nilai-nilai kearifan lokal ini sudah diajarkan secara turun temurun oleh orang tua kepada 
anakanaknya, Karena kearifan lokal merupakan nilai-nilai yang baik dan telah diyakini oleh masyarakat secara turun temurun, maka mengenali unsur-unsur kearifan lokal suatu masyarakat sangat penting dalam proses pemberdayaan dan pembangunan bagi mereka. Seringkali pembangunan dipandang secara keliru, dengan menganggap bahwa pembangunan merupakan perubahan-perubahan nilai, pembangunan gedung-gedung mewah, bahkan transformasi dari masyarakat tradisional ke masyarakat modern. Namun, pembangunan yang baik adalah pembangunan yang berakar dan mempertimbangkan dengan seksama nilainilai lokal yang ada dalam masyarakat. Kearifan lokal adalah dasar untuk pengambilan kebijakan pada level lokal di bidang kesehatan, pertanian, pendidikan, dan pengelolaan sumber daya alam.

B. Pengalokasian Sumber Daya

Sebuah kebijakan akan bermanfaat apabila itu telah diimplementasikan dan keberhasilan suatu implementasi kebijakan sangat ditentukan yang terlibat. Idealnya aktor implementasi kebijakan itu mencakup tiga aktor utama, yakni pemerintah (state), swasta (private) dan masyarakat sipil (civil society) (Jupir, 2013). Kesemua aktor tersebut berafiliasi pada upaya memajukan dan menyukseskan kebijakan. Untuk mengoptimalkan implementasi kebijakan yang menggunakan pendekatan top-down, maka ketersedian sumber daya implementasi harus mumpuni. Menurut Webber (dalam (Jupir, 2013)) mengatakan bahwa supaya seseorang dapat bekerja secara efisien, ia harus memiliki keahlian-keahlian tertentu dan menerapkan secara aktif dan rasional. Setiap anggota harus ahli dalam bidang keterampilan tertentu untuk dapat menjalankan tugas yang dibebankan kepadannya.

Untuk menyatukan visi misi pemerintah daerah dalam pembangunan di Kabupaten Teluk Bintuni, maka di Kabupaten Teluk Bintuni terdapat Forum pemangku kepentingan yang terdiri dari pemerintah, swasta dan masyarakat dalam hal ini perwakilan 7 suku besar di Teluk Bintuni. Dalam forum ini pemda bersama dengan perwakilan masyarakat dan investor menyatukan visi dalam membangun bintuni. Pemda Teluk Bintuni sangat berharap kepada investor bahwa kehadiran para investor haruslah memperhatikan dan memberikan manfaat kepada 7 suku besar yang mendiami Kabupaten Teluk Bintuni. Pembangunan sebagai suatu proses pada hakekatnya merupakan pembaharuan yang terencana dan dilaksanakan dalam tempo yang relatif cepat. Berbagai pembaharuan yang telah dilakukan membawa kita pada kemajuan ilmu pengetahuan dan teknologi, pertumbuhan ekonomi dan kecanggihan sarana komunikasi.

\section{KESIMPULAN}

Kebijakan pembangunan di Kabupaten Teluk Bintuni senantiasa memperhatikan keinginan dari 7 Suku Besar yang ada di Kabupaten Teluk Bintuni. Hal ini mengangdung arti bahwa Pembangunan yang dilakukan dilaksanakan di Kabupaten Teluk Bintuni senantiasa memperhatikan Kearifan lokal atau Local Wisdom yang merupakan gagasan-gagasan atau nilai-nilai, pandangan pandangan setempat atau lokal yang bersifat bijaksana, penuh kearifan, bernilai baik yang tertanam dan diikuti oleh anggota masyarakatnya. Adapun setiap investor yang datang menanamkan modalnya di Kabupaten Teluk Bintuni senantiasa memperhatikan pembangunan 
sumber daya manusia 7 suku besar yang ada di Kabupaten Teluk Bintuni.

\section{DAFTAR PUSTAKA}

Darwis Muhdina. (2015). Kerukanan Umat Beragama Berbasis Kearifan Lokal Di Kota Makassar. Diskursus Islam, 3(1), 20-36.

Edyanto, K. (2018). Leadership Bupati Dalam Pembangunan Di Kabupaten Tambrauw (Studi Kepemimpinan Bupati Tambrauw). Sosio E-Kons, 10(2), 143-149.

Husnul Imtihan, Wahyunadi, F. (2017). Peran Pemerintah Dan Partisipasi Masyarakat Dalam Perencanaan Pembangunan Daerah. Neo-Bis, 11(1). Jupir, M. M. (2013). Implementasi Kebijakan Pariwisata Berbasis Kearifan Lokal. Journal of Indonesian Tourism and Development Studies, 1(1), 28-37.
Ramdhani, A., \& Ramdhani, M. A. (2016). Konsep Umum Pelaksanaan Kebijakan Publik, 1-12.

Safri Miradj, S. (2014). Pemberdayaan Masyarakat Miskin, Melalui Proses Pendidikan Nonformal, Upaya Meningkatkan Kesejahteraan Sosial Di Kabupaten Halmahera Barat. - Jurnal Pendidikan Dan Pemberdayaan Masyarakat, 1(1).

Soares, A., Nurpratiwi, R., \& Makmur, M. (2015). Peran Pemerintah Daerah Dalam Pembangunan Daerah. JISIP: Jurnal Ilmu Sosial Dan Ilmu Politik, 4(2), 231-236. 